\title{
Control of Bean Rust using Antibiotics Produced by Bacillus and Streptomyces species - Translocation and Persistence in Snap Beans
}

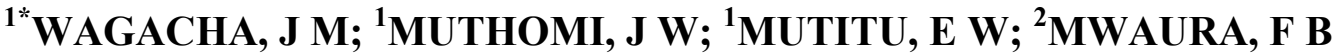

\author{
${ }^{l}$ Department of Plant Science and Crop Protection, , ${ }^{2}$ Department of Botany.
}

University of Nairobi, P. O. Box 30197, Nairobi, Kenya

\begin{abstract}
Antibiotic culture filtrates produced by Bacillus (CA5) and Streptomyces spp. were tested for translocation and persistence when applied on snap beans inoculated with rust (Uromyces appendiculatus) in greenhouse pot experiments. The antibiotics were applied on the first trifoliate leaves and translocation was assessed as the number of rust pustules on non-treated leaflets or trifoliates while persistence was assessed as the number of rust pustules on rust infected plants at different times after antibiotic treatment. The treatments were replicated three times, each replicate consisting of a pot containing three plants. Antibiotics from both Bacillus and Streptomyces were found to have up to $100 \%$ trans-lamina and leaflet-to-leaflet translocation but no significant trifoliate-totrifoliate translocation. The antibiotic culture filtrates also retained significant rust control for up to 10 days after application on the bean plant. However, no significant rust control was found on the plants after 16 days of treatment. The study indicated that the antibiotics produced by antagonistic Bacillus and Streptomyces species possess systemic activity that can persist within the plant for over one week. These metabolites are potential bean rust control products that could be incorporated in integrated disease management programs. @JASEM
\end{abstract}

Snap bean is an important crop in Kenya, contributing about $62 \%$ of the vegetable exports (HCDA, 1999). Bean rust is a common and potentially serious disease of dry and snap beans with a worldwide distribution but is most prevalent in tropical and sub-tropical areas (Robert, 1991). It causes $25-100 \%$ losses depending on stage of infection and the prevailing weather conditions (Schwartz et al., 2004; Robert, 1991). Severe rust infection results in defoliation, stunted growth and subsequent reduced yields while infected pods may be rejected in the market due to the development of disfiguring lesions (Jacques, 2002; Partridge, 1997).

Although chlorothalonil fungicides have been effective in the control of bean rust, various problems have arose including residues on produce, environmental pollution, development of new physiological races and the prohibitive cost (Gerhardson, 2002; Ken et al., 1987). Additionally, they have negative effects on human health and kill possible antagonists (ICIPE, 2006). The main European markets are increasingly becoming intolerant to residues in the horticultural produce (Cesnik, 2006; Shopper, 2006; Mulandi, 1998).

This study was carried out to investigate translocation and persistence of antibiotics from Bacillus and Streptomyces species in controlling bean rust (Uromyces appendiculatus) in snap bean.

\section{MATERIALS AND METHODS}

Antibiotics were produced in Tschen's medium containing glucose $15 \mathrm{~g}$, glycerol $15 \mathrm{mls}$, soybean meal $15 \mathrm{~g}, \mathrm{NH}_{4} \mathrm{SO}_{4} 5 \mathrm{~g}$, yeast extract $1 \mathrm{~g}$, Nacl $5 \mathrm{~g}$, $\mathrm{Caco}_{3} 5 \mathrm{~g}$, per litre (Tschen \& Kou, 1984) for Bacillus sp. and glucose-soyabean medium $(30 \mathrm{~g}$ soybean meal, 20g commercial glucose per litre (Loeffler et al., 1986) for Streptomyces sp. The cultures were incubated at room temperature on a circulatory shaker at $125 \mathrm{rpm}$ for 7 days. Culture filtrates were harvested by centrifugation and concentrated to $30 \%$ by evaporation under vacuum at $60^{\circ} \mathrm{C}$. The filtrates were assayed for antibiotic activity by the paper disc method (Abdel \& Sinclair, 1984) using Fusarium oxysporum and Pythium sp. as the test pathogens for filtrates from Bacillus sp. and Streptomyces sp., respectively. Antibiotic activity was determined by measuring the diameter of clear inhibition zones formed around the paper discs after 48 hours of incubation.

Translocation and persistence experiments were carried out in the green house using snap bean, variety Samantha. Antibiotic culture filtrates were applied at three weeks after germination. The plants were inoculated with bean rust urediospore suspension $\left(2 \times 10^{6}\right.$ spores $\left./ \mathrm{ml}\right)$ containing a few drops of tween 80. For translocation experiments, inoculation was at two days after application of antibiotics and repeated once at 4 days while for the persistence experiments inoculation was done on same day as the antibiotic and repeated at 2, 4, 8, 12 and 16 days. Control plants were sprayed with distilled water. Three aspects of translocation were investigated (i) trans-lamina where the filtrate was applied on the upper surface of the first trifoliate leaf and rust infection observed on the lower surface (ii) leaflet-to-leaflet where filtrate was applied on the first leaflet of the first trifoliate and infection observed on the other leaflets of the same trifoliate (iii) trifoliate-to-trifoliate where filtrate was applied on the first trifoliate and infection observed on the other trifoliate leaves. The experiment was laid out in a completely randomized design (CRD) with 3 replications each containing 3 plants. Disease 
assessment started with the first appearance of rust symptoms and was determined as the number of rust pustules per leaf. Data was analysed using Genstat ${ }^{R}$ 3.0 statistical software.

\section{RESULTS AND DISCUSSION}

Both culture filtrates from Bacillus (CA5) and Streptomyces (CS35) inhibited the growth of Fusarium oxysporum and Pythium spp in culture. Culture filtrates from Bacillus were more effective in suppressing growth of Fusarium oxysporum while culture filtrates from Streptomyces were more effective against Pythium spp. (Table 1). The inhibition zones produced by the two culture filtrates were very clear. Combining the culture filtrates from Bacillus sp. and Streptomyces sp. did not result in increased antibiotic activity. The inhibition zones produced by the combined filtrates against both Fusarium oxysporum and Pythium spp. were faint to moderately faint.

Table 1: Inhibition zones (mm) produced by culture filtrates from Bacillus and Streptomyces spp. and their combination against Fusarium oxysporum and Pythium spp.

\begin{tabular}{lcc}
\hline & Fusarium oxysporum & Pythium spp. \\
Distilled water & $0.000 \mathrm{c}$ & $0.000 \mathrm{c}$ \\
Bacillus (CA5) & $14.111 \mathrm{a}$ & $11.72 \mathrm{~b}$ \\
Streptomyces (CS35) & $12.000 \mathrm{~b}$ & $15.53 \mathrm{a}$ \\
Combined CA5 + CS35 & $12.083 \mathrm{~b}$ & $12.14 \mathrm{~b}$ \\
Mean & 9.549 & 9.85 \\
LSD $(0.05)$ & 0.4031 & 0.728 \\
\hline
\end{tabular}

Values followed by the same letter within columns are not significantly different $(\mathrm{p}=0.05)$

The antibiotics produced by Bacillus CA5 and Streptomyces CS35 were translocated from upper to lower leaf surface and within leaflets of the same trifoliate leaf. Rust infection was completely inhibited on the treated leaves (Table 2). No translocation was observed from one trifoliate leaf to other leaves within the plant. However, the treated leaves exhibited some phytotoxicity, which was expressed as thickening, scorching and early senescence of the leaves. Both culture filtrates from Streptomyces and Bacillus showed significant persistence by inhibiting rust infection for up to 8 days after application. Culture filtrate from Bacillus reduced rust infection by $94.9 \%, 81.7 \%$ and $99.81 \%$ on plants inoculated at 0,4 , and 8 days after application while culture filtrates from Streptomyces reduced infection by $91.7 \%, 81.7 \%$ and $66.7 \%$ respectively (Table 3). No antibiotic activity was observed when inoculation was done 16 days after application of both culture filtrates. The culture filtrates from Bacillus and Streptomyces gave an overall reduction in rust severity of $47.2 \%$ and $27.8 \%$, respectively.

Table 2: Average number of rust pustules on snap bean leaves treated with culture filtrates from Bacillus (CA5) and Streptomyces (CS35) in greenhouse after inoculation with Uromyces appendiculatus.

\begin{tabular}{lccc}
\hline & Bacillus CA5 & Streptomyces & Distilled \\
& & CS35 & water \\
Trans-lamina translocation & $0 \mathrm{~b}$ & $0 \mathrm{~b}$ & $20.21 \mathrm{a}$ \\
Leaflet-to-leaflet translocation & $0 \mathrm{~b}$ & $0 \mathrm{~b}$ & $10.03 \mathrm{a}$ \\
Trifoliate-to-trifoliate translocation & $34.7 \mathrm{a}$ & $41.4 \mathrm{a}$ & $32.4 \mathrm{a}$ \\
Mean & 11.56 & 13.8 & 20.88 \\
\hline
\end{tabular}

Values followed by the same letter(s) within rows are not significantly different $(\mathrm{p}=0.05)$.

The results of this study showed that culture filtrates of Bacillus CA5 and Streptomyces CS35 possess antibiotic activity against different fungal pathogens. The filtrates inhibited the growth of Fusarium oxysporum and Pythium in vitro and bean rust on inoculated plants. The activity of the antibiotic culture filtrates from both Bacillus and Streptomyces against the test fungi differed both in vitro and in vivo. The effectiveness of antibiotics produced by a given antagonist depends on the test pathogen and the type of antibiotic produced (Lee et al., 2005; Yeo and Hol, 1997; Campbell, 1989; Loefler et al., 1986). The antibiotics produced by Bacillus CA5 and Streptomyces CS35 possess limited systemic action as indicated by their translocation within the treated bean leaves. Lack of significant upward translocation could be attributed to dilution effect of weakly active compounds (Dernoeden, 2002). Absorption and translocation of antibiotics can be enhanced by dissolving the active compounds in free oil (Moss, 1989). The activity of antibiotics produced by Bacillus CA5 was more persistent than that of Streptomyces CS35. Persistence of antibiotic activity of commercial formulations of antagonistic bacteria 
has been reported elsewhere (Kiewniek and Jacobsen, 1998). The systemic action and persistence of the antibiotics is of great significance in plant disease control. The active metabolites get absorbed into the plant cells where they are retained and protect the plant from new infections for about 10 days. However, prolonged persistence of chemicals on food crops is not recommended due to current international regulations on maximum residue levels and pre-harvest interval of the treated produce (Grandison, 2006; Wandiembe and Adipala, 2001; Mulandi, 1998; Watson and Koon, 1997). The results indicated that Bacillus (CA5) and Streptomyces (CS35) produced extracellular metabolites that could be useful in the integrated management of rust (Uromyces appendiculatus) in snap beans.

Table 3: Average number of rust pustules on snap bean leaves inoculated at different times with rust spores after treatment with antibiotic culture filtrates from Bacillus (CA5) and Streptomyces (CS35) species

\begin{tabular}{|c|c|c|c|c|c|c|c|c|c|c|c|c|}
\hline \multirow{2}{*}{$\begin{array}{c}\text { Time of } \\
\text { inoculation } \\
\text { (days) }\end{array}$} & \multirow{2}{*}{ Treatment } & \multicolumn{11}{|c|}{ Time after inoculation (days) } \\
\hline & & 10 & 12 & 14 & 16 & 18 & 20 & 22 & 24 & 26 & 28 & Mean \\
\hline \multirow[t]{2}{*}{0} & water & $7 \mathrm{a}$ & $9 a$ & $11 \mathrm{a}$ & $13 a$ & $18.7 \mathrm{a}$ & $33 a$ & $48 \mathrm{a}$ & $65.7 \mathrm{a}$ & $76.7 \mathrm{a}$ & $93.3 \mathrm{a}$ & $37.5 \mathrm{a}$ \\
\hline & CA5 & $0 \mathrm{a}$ & $0.2 b$ & $0.2 \mathrm{~b}$ & $0.2 b$ & $1.2 \mathrm{~b}$ & $1.2 \mathrm{~b}$ & $1.2 \mathrm{~b}$ & $3.7 \mathrm{~b}$ & $4.8 \mathrm{~b}$ & $6.3 \mathrm{c}$ & $1.9 \mathrm{~b}$ \\
\hline \multirow[t]{3}{*}{4} & water & $1.7 \mathrm{a}$ & $3.5 \mathrm{a}$ & $5.7 \mathrm{a}$ & $16.3 \mathrm{a}$ & $28 \mathrm{a}$ & $42 a$ & $55.5 \mathrm{a}$ & $65.8 \mathrm{a}$ & $79.5 \mathrm{a}$ & $93.5 \mathrm{a}$ & $39.1 \mathrm{a}$ \\
\hline & CS35 & $0 \mathrm{a}$ & $0.3 \mathrm{a}$ & $1.3 \mathrm{a}$ & $2.3 \mathrm{~b}$ & $3.5 b$ & $6.3 b$ & $8.7 b$ & $10.7 \mathrm{~b}$ & $17 \mathrm{~b}$ & $23.8 \mathrm{~b}$ & $7.4 \mathrm{~b}$ \\
\hline & CA5 & $0 \mathrm{a}$ & $0 \mathrm{a}$ & $0 \mathrm{a}$ & $2 b$ & $3.2 \mathrm{~b}$ & $5.5 b$ & $9.3 b$ & $13.8 \mathrm{~b}$ & $16.5 b$ & $23.8 \mathrm{~b}$ & $7.4 \mathrm{~b}$ \\
\hline \multirow[t]{3}{*}{8} & water & $0.2 \mathrm{a}$ & $7.3 \mathrm{a}$ & $33.5 \mathrm{a}$ & $58.3 \mathrm{a}$ & $73.3 \mathrm{a}$ & $90.3 \mathrm{a}$ & $105.3 \mathrm{a}$ & $132 \mathrm{a}$ & $149.8 \mathrm{a}$ & $177.7 \mathrm{a}$ & $82.8 \mathrm{a}$ \\
\hline & CS35 & $0.2 \mathrm{a}$ & $1.3 \mathrm{a}$ & $10.3 \mathrm{~b}$ & $19.5 b$ & $23.8 \mathrm{~b}$ & $29.7 b$ & $35.3 b$ & $42.7 b$ & $51 \mathrm{~b}$ & $62.3 b$ & $27.6 \mathrm{~b}$ \\
\hline & CA5 & $2 \mathrm{a}$ & $3 a$ & $6.7 b$ & $9.7 b$ & $11.7 \mathrm{~b}$ & $14 \mathrm{~b}$ & $16.8 \mathrm{c}$ & $22.3 c$ & $30.2 \mathrm{c}$ & $38 \mathrm{c}$ & $15.4 \mathrm{~b}$ \\
\hline \multirow[t]{5}{*}{12} & water & $21.8 \mathrm{a}$ & $27.3 \mathrm{a}$ & $34.5 \mathrm{ab}$ & $42 b$ & $49.2 b$ & $86 a$ & $125.5 \mathrm{a}$ & $151.2 \mathrm{a}$ & $191.2 \mathrm{a}$ & $231.2 \mathrm{a}$ & $96.0 \mathrm{a}$ \\
\hline & CS35 & $24 \mathrm{a}$ & $34.3 \mathrm{a}$ & $49.2 \mathrm{a}$ & $62.7 \mathrm{a}$ & $83 a$ & $103.7 \mathrm{a}$ & $125.3 \mathrm{a}$ & $149.7 \mathrm{a}$ & $174.7 \mathrm{a}$ & $206 b$ & $101.2 \mathrm{a}$ \\
\hline & CA5 & $6.2 \mathrm{a}$ & $19.2 \mathrm{a}$ & $23.8 b$ & $28.5 b$ & $31.3 \mathrm{~b}$ & $51.8 \mathrm{~b}$ & $67.3 b$ & $88 \mathrm{~b}$ & $113.5 b$ & $157.8 \mathrm{c}$ & $58.8 \mathrm{~b}$ \\
\hline & CS35 & $33.2 \mathrm{a}$ & $46.3 \mathrm{a}$ & $66.2 \mathrm{a}$ & $77 \mathrm{a}$ & $94.5 \mathrm{a}$ & $117.3 \mathrm{a}$ & $147.5 \mathrm{a}$ & $176.5 \mathrm{a}$ & $211.8 \mathrm{a}$ & $238.5 \mathrm{a}$ & $120.9 \mathrm{a}$ \\
\hline & CA5 & $18.8 \mathrm{a}$ & $36.7 \mathrm{a}$ & $57.7 \mathrm{a}$ & $62 \mathrm{ab}$ & $81.3 \mathrm{a}$ & $102.2 \mathrm{ab}$ & $130 \mathrm{ab}$ & $159.2 \mathrm{a}$ & $189.3 b$ & $230 a$ & $106.7 \mathrm{a}$ \\
\hline
\end{tabular}

Values followed by same letter(s) within columns (same day of inoculation) are not significantly different ( $\mathrm{p}=0.05)$

Acknowledgement: This study was funded by the University of Nairobi and the Agricultural Research Fund (ARF) of the Kenya Agricultural Research Institute (KARI).

\section{REFERENCES}

Abdel, H; Sinclair, J B (1964). Inhibition of Xanthomonas malvacearum by certain fungicides and antibiotics. Plant Disease Reporter 48:268-269

Campbell, R (1989). Biological control of plant pathogens. Cambridge University Press, New York.

Cesnik, H B; Gregorcic, A; Bolta, S V (2006). Pesticide residues in agricultural products of Slovene origin in 2005. Acta Chim Slov 53:9599.

Dernoeden, P H (2002). Fungicides: plant uptake and mode of action. Golf and Sports Turf. Australia Magazine, Article 102.

Gerhardson, B (2002). Biological substitutes for pesticides. Trends Biotechnology 20:338-343.

Grandison, A S (2006). Post harvest handling and preparation of foods for processing. Food
Processing Handbook, Wiley-VCH Verlag GmbH \&Co. KgaA, Weinheim, Germany.

Horticultural Crops Development Authority (HCDA) (1999). Horticultural News No. 20, Nairobi, Kenya.

ICIPE (2006). African insect science for food and health. http://www.icipe.org

Jacques, D (2002). Bean diseases and their control. Agriculture and Agri-food Canada. http://www.agr.gc.ca

Ken, P; Francis, J; George, W; Fong, W (1987). Strategies for chemical control of rust on Snapbean in Florida and their compatibility with Canadian residue tolerances. Plant Disease 71:639-642.

Kiewnick, S; Jacobsen, J (1998). Biological control of Fusarium dry rot on potato with antagonistic bacteria in commercial formulation. Phytopathology 88: 47.

Lee, H B; Kim, Y; Choi, G J; Park, S H; Kim, C J; Jung, H S (2005). Activity of some aminoglycoside antibiotics against true fungi, Phytophthora and Pythium species. Journal of Applied Microbiology 99:836. 
Loeffler, W S; Tschen, S M; Vannitankom, N; Kugler, M; Knorpp, E; Hscieh, T F; Wu. T G (1986). Antifungal effect of bacilysin and fengymycin from Bacillus antibiotics. Phytopathology 155:204-213.

Moss, V D (1989). Antibiotics for control of blister rust on western white pine. Forest Science 7: 380-396.

Mulandi, M A S (1998). Fresh and processed horticultural exports. The Horticulture Newsletter 1(2): 5, Kenya.

Partridge, J E (1997). Rust of Dry Beans. University of Nebraska-Lincoln, Department of Plant Pathology.

Robert, H (1991). Compedium of Bean Diseases. McMillan Education Ltd., London.
Schwartz, H F; Steadman, J R; Lindgren, D T (2004). Rust of dry beans. Cooperative Extension, Colorado State University, USA. http://www.ext.colostate.edu

Shopper, S (2006). French beans. http://www.wine.telegraph

Tshen, J S M; Kou, W L (1984). Antibiotic situation and control of Rhizoctonia solani by Bacillus subtilis. Plant Protection Bulletin (Tarpei) 14:222-232.

Wandiembe, S; Adipala, E (2001). Assessment of pesticide residue effects on cowpea grown in Uganda. African Crop Science Conference Proceedings, Vol.5. pp 141-146.

Watson, A G; Koons, C E (1997). Increased tolerance to benomyl in greenhouse populations of Botrytis cinerea. Phytopathology 60:1489.

Yeo, W H; Hol, K Y (1997). Physical chemical characteristics and antiviral activity of ASA an antibiotic produced by actinomycetes B25. Korean Journal of Plant Pathology 13:63-68 